IJCCS (Indonesian Journal of Computing and Cybernetics Systems)

Vol.14, No.3, July 2020, pp. 265 276

ISSN (print): 1978-1520, ISSN (online): 2460-7258

DOI: https://doi.org/10.22146/ijccs.55632

\title{
An Expert System of Chicken Disease Diagnosis by Using Dempster Shafer Method
}

\author{
Yaqutina Marjani Santosa*1, Suprapto $^{2}$, Wahyono ${ }^{3}$ \\ ${ }^{1}$ Master Program in Computer Science, FMIPA UGM, Yogyakarta, Indonesia \\ ${ }^{2,3}$ Department of Computer Science and Electronics, FMIPA UGM, Yogyakarta, Indonesia \\ e-mail: *1yaqutina.marjani.s@mail.ugm.ac.id, ${ }^{2}$ sprapto@ugm.ac.id, ${ }^{3}$ wahyo@ugm.ac.id
}

\begin{abstract}
Abstrak
Ayam merupakan hewan yang memberikan banyak manfaat bagi kehidupan manusia, daging dan telurnya digunakan sebagai bahan pangan untuk memenuhi kebutuhan pangan manusia, kotorannya dapat dijadikan pupuk, dan tidak sedikit yang memanfaatkannya untuk dijadikan hewan ternak. Meskipun memberikan banyak manfaat, namun bagi peternak dalam pemeliharaannya menemui beberapa kendala yang harus dihadapi seperti terserang penyakit, sanitasi lingkungan yang buruk, serta produksi telur yang menurun. Dari beberapa kendala yang telah disebutkan, yang paling sering dihadapi adalah hewan terserang penyakit pada hewan ternak. Berdasarkan hasil wawancara yang telah dilakukan kepada beberapa peternak ayam, dapat dikatakan bahwa pengetahuan para peternak ayam terhadap penyakit ayam dan penanganannya masih sangat kurang. Namun jumlah pakar yang memahami dan mengetahui tentang jenis penyakit ayam dan cara penanganannya terbatas, maka dibutuhkan sebuah sistem pakar yang dapat menirukan pengetahuan dan pemahaman pakar untuk mengatasi permasalahan tersebut. Berdasarkan kajian pustaka yang telah dilakukan, metode yang cocok untuk digunakan pada sistem pakar adalah metode dempster shafer dengan mengolah nilai belief pada suatu penyakit. Metode dempster shafer merupakan metode yang digunakan untuk menghitung ketidakpastian akibat adanya penambahan maupun pengurangan fakta baru yang akan mengubah aturan yang ada. Berdasarkan pengujian pada 40 kasus dengan menggunakan sistem pakar yang menerapkan metode dempster shafer, diperoleh hasil persentase kecocokan diagnosa yang diberikan oleh pakar dan sistem sebesar $95 \%$.
\end{abstract}

Kata kunci-Sistem Pakar, Penyakit Ayam, Dempster Shafer

\begin{abstract}
Chicken is an animal that can provide many benefits for human life, meat and eggs can be used as food to fulfill the needs of human food, the excrement can be made fertilizer, and frequently its be used as a farm animal. Although it can provide many benefits, but for chicken farmers, the maintenance of chicken meet some obstacles that must be faced such as disease, poor environmental sanitation, and the production of eggs are declining. From some of the obstacles that have been mentioned, the most frequently encountered are animals infected with the disease. Based on the results of interviews that have been done to some chicken farmers, it can be said that the knowledge of chicken farmers against chicken disease and its handling is still very lacking. But the number of experts who understand and know about the type of chicken disease and the way of handling is limited, then it takes an expert system that can simulate knowledge and understanding of experts to overcome the problem. Based on the study of the libraries, the method suitable for use in the expert system is the Dempster shafer method by processing the value of belief in a disease. Dempster shafer method is a method used to calculate uncertainty due to the addition or reduction of new facts that will change the existing rules. Based on tests in 40 cases using an expert system applying the Dempster Shafer method, obtained the percentage of diagnostic compatibility result given by experts and system is $95 \%$.
\end{abstract}

Keywords - Expert System, Chicken Disease, Dempster shafer

Received April 23 ${ }^{\text {th }}, 2020 ;$ Revised July 18 ${ }^{\text {th }}, 2020 ;$ Accepted April $30^{\text {th }}, 2020$ 


\section{INTRODUCTION}

Chicken is a beneficial animal for humans to fulfill the needs of animal proteins. According to data from Badan Pusat Statistik [1], chicken is one of the many food needs in the consumption of each province in Indonesia. So, in every province there is a chicken farm to meet these needs. In the maintenance of chickens there are obstacles that must be faced such as disease attacks, poor environmental sanitation and egg production is declining.

The most commonly encountered obstacle is the recurrence of disease in chickens. Retno, F. D et al [2] did a research on chicken diseases that found that some viral and bacterial animal husbandry can cause death in farm animals. The attack of this disease if it is not detected from the beginning then it will cause a huge loss in the present day. Causes of the rate of chicken mortality due to the incubation period of chicken against the disease is very short so that a quick treatment is required.

Interviews conducted on several breeders concluded. Farmer knowledge about chicken disease is still minimal, so if there are chickens that sick farmers do not know the disease that is in the pain of chickens. During this time, farmers rely on field worker officers (PPL) who routinely check on the condition of the farm. PPL is not a veterinarian but rather a staff who is given the task to check out farm animals. Because of the limited members who understand about chicken disease so it takes an expert system to overcome it.

The expert system is one of the branches of artificial intelligence that uses knowledge a special knowledge owned by an expert to solve a particular problem [3]. This system is used to duplicate or simulate expert-owned skills to solve problems. This system stores expert expertise in a knowledge base and uses reasoning that is possessed by experts to solve problems. This expert system helps solve problems by diagnosing the symptoms of the user. With a system of expert users can diagnose the disease by answering questions that are based on symptoms. In the diagnosis, the user consult a doctor.

Research on the diagnosis of disease in chickens has been done before. In the study used the certainty factor (cf) method to perform the tracking process in its conclusion. The results obtained from the research are less satisfactory because the weight CF In conclusion is worth 1.2 that does not meet the rules of the weight value CF [4]. Various factors that can affect the $\mathrm{CF}$ weight include low weight value, fault in system and probability factor after calculating.

Withdrawal of conclusions to obtain the results of the diagnosis sometimes has a difference between one expert and another, that is because there is difference knowledge among experts who are one with other experts. In addition, the difference in the results of the diagnosis can be caused by the presence of a type of disease that has symptoms similar to other diseases, such as Colibacillus, cholera, and Salmonellosis disease, the disease has a similar symptom of one with the other. So, in the withdrawal of conclusions have a difference.

The study of the libraries that have been done, methods on the expert system suitable for use is the method of Dempster Shafer by processing the value of belief in a disease. Dempster Shafer Method is a method used to calculate uncertainty due to the addition or reduction of new facts that will change the existing rules. Dempster Shafer method can perform data processing of more than two data by using combination method without having to perform repeated processing.

A conclusion for the diagnosis of the disease by considering the data that is input without having to check against all diseases. So, this study proposed the application of Dempster Shafer Method for chicken disease diagnosis expert system. This system receives data derived from expert knowledge and disease case data. From that data the system will do inference and display the diagnosis of chicken diseases.

Darwan [5] conducts diagnostic research on chicken disease caused by viruses by using the certainty factor method to handle the imposition and use of forward chainning inference machines. The results of expert systems have not the same accuracy. Achmadi [6] directly uses the certainty factor method to detect viral infections, an expert system can be used to detect

IJCCS Vol. 14, No. 3, July 2020 : 265 - 276 
diseases. Meanwhile, Setioyadi [7] and Gunawan [8] use the same method that generates accuracy of $90 \%-93 \%$.

Research system experts using Dempster Shafer method has been done by some people. Trismayanti [9] did research by implementing VCIRS and Dempster Shafer methods. The Vcirs method is used as the rule of uncertainty that has been made based on the expert data. The Dempster Shafer method is used to seek uncertainty due to the addition and reduction of new facts. The results of the study resulted in $100 \%$ accuracy.

Rusdi [10] was in his research using forward chainning expert systems as well as the method of uncertainty Dempster Shafer. This research provides information on the diagnosis of gastrointestinal endoparasitism, parasitic life-cycle and therapeutic advice given to animals belonging to the disease. Michel [11] and Luthfi [12] with the same method yielded 90\%-96\% accuracy.

\section{METHODS}

\subsection{Dempster Shafer Method}

The dempster theory was introduced in the book Mathematical Theory Of Evidence in 1976 by the Shafer [3]. The Dempster Shafer theory is used to solve uncertainty problems. This uncertainty is due to the addition of new facts. Dempster-Shafer Theory Of Evidence shows a way to give the confidence of the beliefs in accordance with the facts collected. The DempsterShafer theory is a representation, combination and propogation of uncertainty, wherein this theory has some characteristic that instutitive according to how an expert thinks, but a strong mathematical basis. In general, the Dempster-Shafer theory is written in an interval: [Belief, Plausibility] [13].

Dempster-Shafer uses a probability theory, in which the evidence is attributed to one possible event while in evidence Dempster-Shafer is associated with several events. Probability is used to declare levels or degrees of trust. Probability values are between 0 and 1 . P (A | B) interpreted as the degree or belief level that A is true with the given B [3]. Dempster-Shafer The level of belief of a evidence is called the degree of belief assumed as mass (m). Mass function (m) in the theory of Dempster-Shafer is the level of belief of a evidence, often referred to as evidence measure so that it is narrated by $\mathrm{m}$. The goal is to associate the belief size of $\theta$ elements. Not all of the evidence directly supports each element. Therefore, there needs to be a probability of density function $\mathrm{m}$. The value of $\mathrm{m}$ not only defines the elements of $\theta$ only, but also all its subsets. So if $\theta$ contains $n$ elements, then a subset of $\theta$ is $2 \mathrm{n}$. The sum of all $\mathrm{m}$ in a subset of $\theta$ equals 1 . If there is no information to select the hypothesis, then the value: $\operatorname{m}\{\theta\}=1$ and 0 .

In the process of combination evidence allows for the occurrence of a conflict between evidence. Conflict of evidence occurs when the absence of elements produced in the cross product between evidence, for example a combination of evidence $m\{A\}$ and $m\{B\}$ that does not result in a $\varnothing$ element. To solve this problem, a process of normalization of evidence is required by defining evidential conflict $(\mathrm{k})$ into the Dempster's Rule of Combination in Equation $1[3]$.

$$
m_{1} \oplus m_{2}(z)=\frac{\sum_{\mathbb{Z n Y} Y=\mathbb{Z}} m_{1}(X) m_{2}(Y)}{1-\sum_{\mathbb{Y} \cap Y=0} m_{1}(X) m_{2}(Y)}
$$

Where:

$m_{1} \oplus m_{2}(Z) \quad$ : Results of the combination of evidence $(X)$ and Evidence $(Y)$

$m_{l}(X) \quad$ : Mass function of Evidence $(X)$, which is derived from the value of belief Of the evidence multiplied by the disbelief value

$m_{2}(Y) \quad:$ Mass function of Evidence $(Y)$, which is derived from the value of belief

Of the evidence multiplied by the disbelief value 


\subsection{Certainty Factor Method}

The Certainty Factor method is one of the methods used to resolve uncertainty problems, developed for the MYCIN expert system by Shortliffe [3]. The value given by MYCIN to demonstrate its large level of certainty is the Certainty Factor (CF). Here's the CF equation that MYCIN developed is demonstrated by [3].

$$
\mathrm{CF}(\mathrm{H}, \mathrm{E})=\mathrm{MB}(\mathrm{H}, \mathrm{E})-\mathrm{MD}(\mathrm{H}, \mathrm{E})
$$

Where :

$\mathrm{CF}(\mathrm{H}, \mathrm{E})$ : Certainty factor of the $\mathrm{H}$ hypothesis which is influenced by evidence $\mathrm{E}$

$\mathrm{MB}(\mathrm{H}, \mathrm{E})$ : Measure of increased confidence in the $\mathrm{H}$ hypothesis that was influenced by evidence $\mathrm{E}$

$\mathrm{MD}(\mathrm{H}, \mathrm{E})$ : Measure the rise of distrust towards the $\mathrm{H}$ hypothesis influenced by evidence $\mathrm{E}$

Suppose another rule concluded the same hypothesis but with different certainty factors. The certainty factor rules that include the same hypothesis are calculated from the combination functions for the certainty factor shown in Equation 3 [3].

CFcombination $(\mathrm{CF} 1, \mathrm{CF} 2)=$

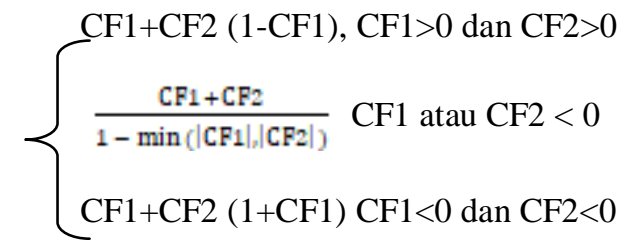

\subsection{Expert system Architecture}

The main parts that make up the expert system are the development environment and the consultation environment [14]. The development environment is used by experts to incorporate expert knowledge into expert systems. The consulting environment is used by users to gain knowledge from experts through an expert system. The expert system components can be shown in Figure 1.

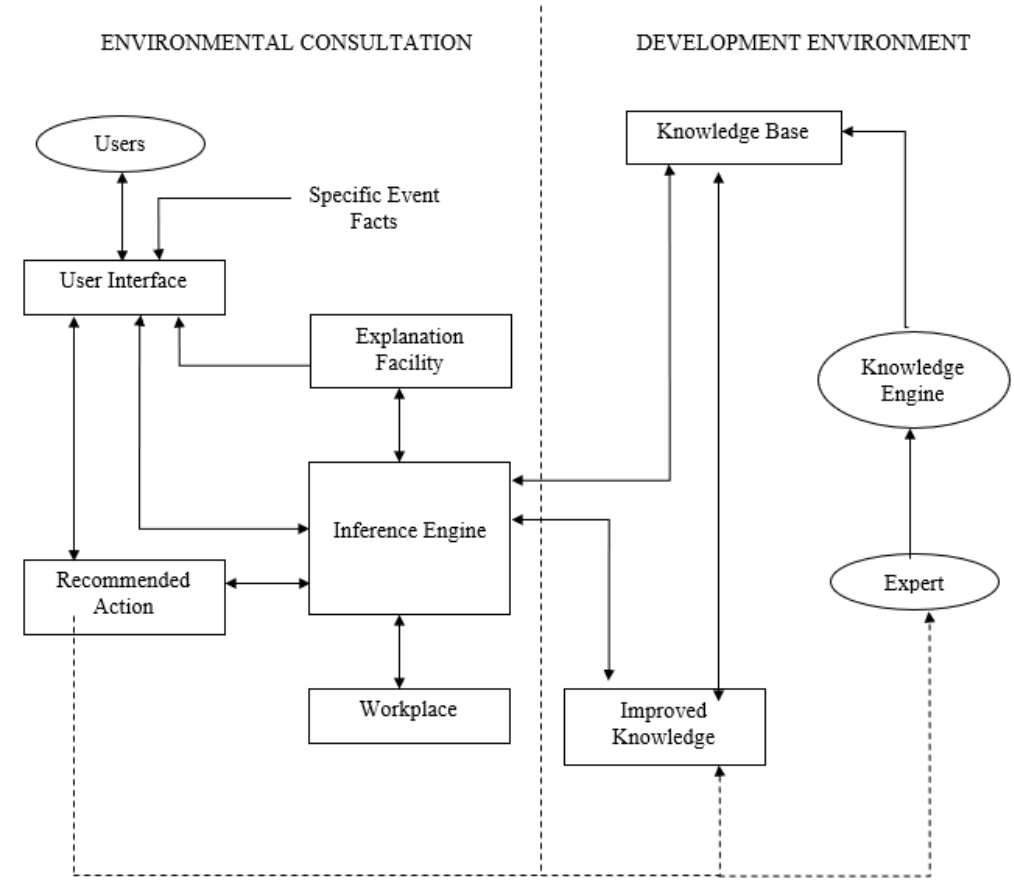

Figure 1 Expert System Architecture

IJCCS Vol. 14, No. 3, July 2020 : 265 - 276 


\subsection{Dempster Shafer Method Flowcart}

The process of taking diagnosis of chicken disease can be seen in Figure 2 . In designing this expert system using dempster shafer method, which is starting from : Users enter facts about the symptoms of chicken disease. Furthermore, the checking of the symptoms that are inputed if the number of symptoms $(=1)$, then will be found diagnosis of disease $\{X\}$, but if the answer to the number of symptoms $(>=2)$, then the calculation of each symptom. Further checking of the disease intersection in the symptoms, if the intersection is not an empty set $(\{\})$, then proceed with the combination process, otherwise obtained the result "disease not found". After the many symptoms $(=2)$, the calculation process is done with the combination function, for the $X$ subset of $\theta$, With $m_{1}$ as its density function and $\mathrm{Y}$ is also a subset of $\theta$, With $\mathrm{m}_{2}$ as its density function, then it can be formed function combinations of $m_{1}$ and $m_{2}$ as $m_{3}$. Checked for all symptoms, if finished, the largest value of mass function, so that the result of diagnosis with the biggest value of density, otherwise it will be checked again to the symptoms until the process is completed.

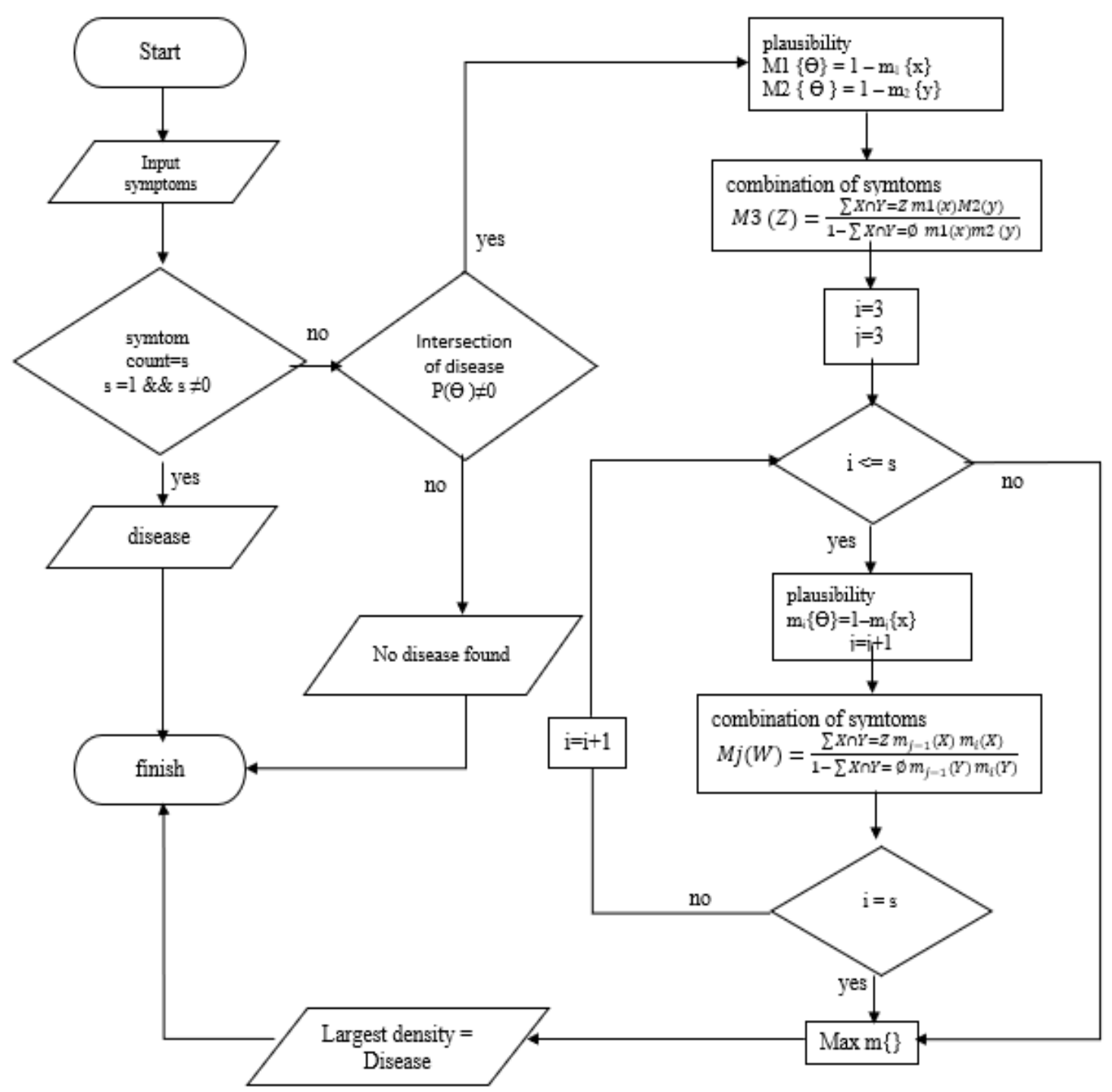

Figure 2 Dempster Shafer Method Flowcart 


\subsection{Illustration of the Dempster Shafer Method}

Illustrations of Dempster Shafer Method are obtained from the symptoms which are then carried out calculation of the resulting disease. Example of calculation on the Dempster Shafer Method when the symptoms of paralysis (G15), tremor head to neck (G37) and decreased egg production (G25).

Symptom 1: Paralysis (G15)

The first step is to calculate the value of belief and the ceiling of the symptoms of paralysis which is a diagnosis of the disease of Avian Encephalomytelitis (AE) with a value of belief (0.9).

$$
\begin{aligned}
& \operatorname{m} 1\{\mathrm{AE}\}=0,9 \\
& \operatorname{m1}\{\theta\}=1-\{\mathrm{AE}\} \\
& =1-0,9 \\
& =0,1
\end{aligned}
$$

Symptom 2: Tremor on the head and neck (G37)

Then found a new fact is to calculate the value of belief and the ceiling of the symptoms of tremor on the head and neck which is a diagnosis of diseases of Avian Encephalomytelitis (AE) with a value of belief (1)

$$
\begin{aligned}
& \mathrm{m} 2\{\mathrm{AE}\}=1 \\
& \mathrm{~m} 2\{\theta\}=1-\{\mathrm{AE}\} \\
& =1-1 \\
& =0
\end{aligned}
$$

Table 1 Illustration of beliefs values against two symptoms

\begin{tabular}{|l|c|c|}
\hline & $\mathrm{m} 2\{\mathrm{AE}\} 1$ & $\mathrm{~m} 2\{\boldsymbol{\theta}\} 0$ \\
\hline $\mathrm{m} 1\{\mathrm{AE}\} 0,9$ & $\{\mathrm{AE}\} 0,9$ & $\{\mathrm{AE}\} 0$ \\
\hline $\mathrm{m} 1\{\boldsymbol{\theta}\} 0,1$ & $\{\mathrm{AE}\} 0,1$ & $\{\boldsymbol{\theta}\} 0$ \\
\hline
\end{tabular}

Next based on table 1 calculate the level of confidence that has been combined. Hence the value of his belief as follows.

$$
\begin{aligned}
& \mathrm{m} 3\{\mathrm{AE}\}=\frac{0.9+0.1+0}{1-0}=1 \\
& \mathrm{~m} 3\{\theta\}=\frac{0}{1-0}=0
\end{aligned}
$$

Symptom 3: Decreased egg production (G25)

Then found a new fact is to calculate the value of belief and the ceiling of the decline in egg production which is a diagnosis of diseases of Avian Encephalomytelitis (AE) with a value of belief $(0.8)$.

$$
\begin{aligned}
& \mathrm{m} 4\{\mathrm{AE}\}=0,8 \\
& \begin{aligned}
\mathrm{m} 4\{\boldsymbol{\theta}\} & =1-\{\mathrm{AE}\} \\
& =1-0,8 \\
& =0,2
\end{aligned}
\end{aligned}
$$


Table 2 Illustration of combination confidence value

\begin{tabular}{|l|c|c|}
\hline & $\mathrm{m} 4\{\mathrm{AE}\} 0.8$ & $\mathrm{~m} 4\{\theta\} 0.2$ \\
\hline $\mathrm{m} 3\{\mathrm{AE}\} 1$ & $\{\mathrm{AE}\} 0.8$ & $\{\mathrm{AE}\} 0.2$ \\
\hline $\mathrm{m} 3\{\boldsymbol{\theta}\} 0$ & $\{\mathrm{AE}\} 0$ & $\{\theta\} 0$ \\
\hline
\end{tabular}

Next based on table 2 calculates the level of confidence that has been combined. Hence the value of his belief as follows.

$$
\begin{aligned}
& \mathrm{m} 5\{\mathrm{AE}\}=\frac{0.8+0.2+0}{1-0}=1 \\
& \mathrm{~m} 5\{\theta\}=\frac{0}{1-0}=0
\end{aligned}
$$

After the calculation of the combination of the three symptoms, the biggest belief is obtained by Avian Encephalomytelitis (AE) with a value of 1. If there are cases that have more than one symptom it will use a combination calculation that will seek the confidence level of both rules. If obtained the highest value of the combination then used to determine the diagnosis of disease in chickens.

\subsection{Expert system implementation}

A built-in system of experts is a web-based system with the foundation of its creation using the PHP programming language. Whereas, the database on the system uses a MySQL database. Implementing the implementation of the system uses a flowchart as well as DFD that has been designed in the planning analysis chapter. The interface implementation of the expert system can be seen in Figure 3. The page that appears first when accessing the expert system is the home page. The home page on the user and admin view has the same view.

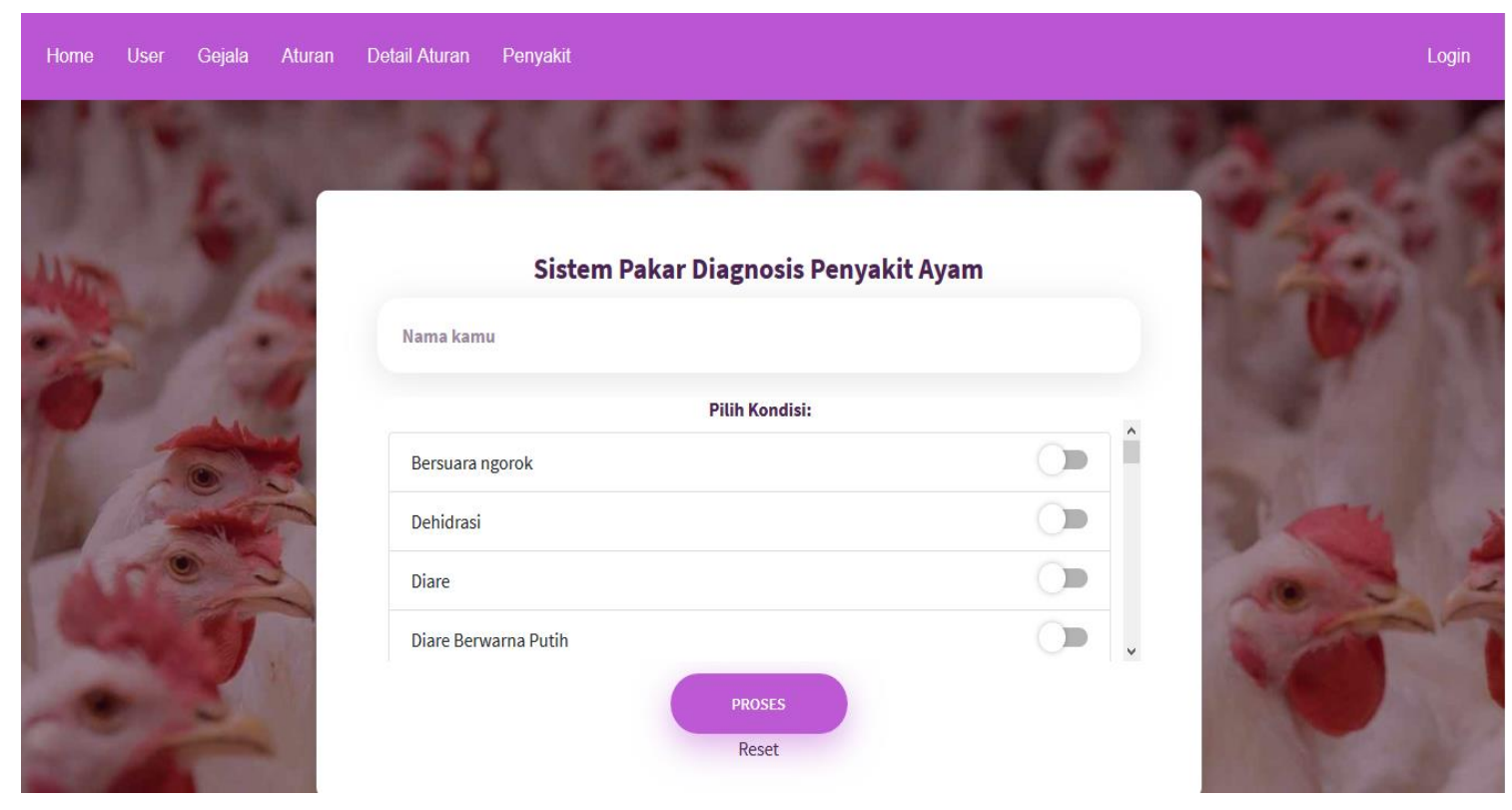

Figure 3 Expert System interface 


\section{RESULTS AND DISCUSSION}

At this stage is outlined about the testing comparison of certainty factor methods and the dempster shafer methods by input the same symptoms for both methods. Weights to determine certainty value and belief value using medical record of the disease.

On the Dempster Shafer method use the value of confidence to determine the disease. This method uses disease-related symptoms without calculating the whole disease. The result of the combination of symptoms will result in conclusions with the highest percentage used in conclusion of the disease.

Conduct trials against 40 cases by entering the same symptoms. The comparison results can be seen in table 3 . After the trial in 40 cases were obtained a higher percentage of demspter shafer methods compared to certainty factor method. In the case of 19, 28, 29 and 40 certainty factor methods have different results with the results that experts have given.

Table 3 Comparison of Certainty Factor and Dempster Shafer method results

\begin{tabular}{|c|c|c|c|c|c|c|}
\hline No & Symptoms & Experts & Certainty Factor & $\begin{array}{c}\text { Level } \\
\text { Certainty }\end{array}$ & Dempster Shafer & $\begin{array}{l}\text { Level } \\
\text { Belief }\end{array}$ \\
\hline 1 & $\begin{array}{l}\text { Breathable open } \\
\text { mouth, nasal } \\
\text { congestion mucus } \\
\text { (pileks) }\end{array}$ & $\begin{array}{c}\text { Chronic } \\
\text { Respiratory } \\
\text { Disease (CRD) }\end{array}$ & $\begin{array}{c}\text { Chronic } \\
\text { Respiratory } \\
\text { Disease (CRD) }\end{array}$ & $81 \%$ & $\begin{array}{l}\text { Chronic Respiratory } \\
\text { Disease (CRD) }\end{array}$ & $90 \%$ \\
\hline 2 & $\begin{array}{l}\text { Skinny body, dull } \\
\text { fur, breathable open } \\
\text { mouth }\end{array}$ & $\begin{array}{c}\text { Chronic } \\
\text { Respiratory } \\
\text { Disease (CRD) }\end{array}$ & $\begin{array}{c}\text { Chronic } \\
\text { Respiratory } \\
\text { Disease (CRD) }\end{array}$ & $70 \%$ & $\begin{array}{l}\text { Chronic Respiratory } \\
\text { Disease (CRD) }\end{array}$ & $70 \%$ \\
\hline 3 & $\begin{array}{l}\text { Lean body, nasal } \\
\text { congestion (pileks), } \\
\text { dehydration }\end{array}$ & $\begin{array}{c}\text { Chronic } \\
\text { Respiratory } \\
\text { Disease (CRD) } \\
\end{array}$ & $\begin{array}{c}\text { Chronic } \\
\text { Respiratory } \\
\text { Disease (CRD) } \\
\end{array}$ & $87 \%$ & $\begin{array}{l}\text { Chronic Respiratory } \\
\text { Disease (CRD) }\end{array}$ & $78.4 \%$ \\
\hline 4 & $\begin{array}{l}\text { Mata Swollen eyes, } \\
\text { fishy eyes, no } \\
\text { appetite }\end{array}$ & $\begin{array}{l}\text { Infectious Coryza } \\
\text { (SNOT) }\end{array}$ & $\begin{array}{l}\text { Infectious Coryza } \\
\text { (SNOT) }\end{array}$ & $93 \%$ & $\begin{array}{c}\text { Infectious Coryza } \\
\text { (SNOT) }\end{array}$ & $100 \%$ \\
\hline 5 & $\begin{array}{l}\text { Swollen eyes, } \\
\text { dehydration, dull fur }\end{array}$ & $\begin{array}{l}\text { Infectious Coryza } \\
\text { (SNOT) }\end{array}$ & $\begin{array}{c}\text { Infectious Coryza } \\
\text { (SNOT) }\end{array}$ & $60 \%$ & $\begin{array}{c}\text { Infectious Coryza } \\
\text { (SNOT) }\end{array}$ & $74.4 \%$ \\
\hline 6 & $\begin{array}{l}\text { Can not stand, thin } \\
\text { skin, no appetite }\end{array}$ & Gout & Gout & $86 \%$ & Gout & $100 \%$ \\
\hline 7 & $\begin{array}{l}\text { Can not stand, red } \\
\text { color on the skin, not } \\
\text { appetite }\end{array}$ & Gout & Gout & $86 \%$ & Gout & $100 \%$ \\
\hline 8 & $\begin{array}{l}\text { Swollen femur } \\
\text { joints, red color on } \\
\text { the skin }\end{array}$ & Gout & Gout & $91 \%$ & Gout & $94 \%$ \\
\hline 9 & $\begin{array}{l}\text { Paralysis, decreased } \\
\text { egg production }\end{array}$ & $\begin{array}{c}\text { Avian } \\
\text { Encephalomytelitis } \\
\text { (AE) }\end{array}$ & $\begin{array}{c}\text { Avian } \\
\text { Encephalomytelitis } \\
\text { (AE) }\end{array}$ & $67 \%$ & $\begin{array}{c}\text { Avian } \\
\text { Encephalomytelitis } \\
\text { (AE) }\end{array}$ & $80 \%$ \\
\hline 10 & $\begin{array}{l}\text { Paralysis, Tremor } \\
\text { head to neck }\end{array}$ & $\begin{array}{c}\text { Avian } \\
\text { Encephalomytelitis } \\
\text { (AE) }\end{array}$ & $\begin{array}{c}\text { Avian } \\
\text { Encephalomytelitis } \\
\text { (AE) }\end{array}$ & $93 \%$ & $\begin{array}{c}\text { Avian } \\
\text { Encephalomytelitis } \\
\text { (AE) }\end{array}$ & $100 \%$ \\
\hline 11 & $\begin{array}{l}\text { Grayed-out Bungkul, } \\
\text { respiratory disorders }\end{array}$ & Chickenpox (CA) & Chickenpox (CA) & $48 \%$ & Chickenpox (CA) & $54 \%$ \\
\hline 12 & $\begin{array}{l}\text { Bungkul under the } \\
\text { airways, respiratory } \\
\text { disorders, there is a } \\
\text { Kerompeng }\end{array}$ & Chickenpox (CA) & Chickenpox (CA) & $90 \%$ & Chickenpox (CA) & $100 \%$ \\
\hline 13 & $\begin{array}{l}\text { Diarrhea, lethargy, } \\
\text { abnormal fur growth }\end{array}$ & $\begin{array}{c}\text { Hellicopter } \\
\text { Desease (HD) }\end{array}$ & $\begin{array}{c}\text { Hellicopter } \\
\text { Desease (HD) }\end{array}$ & $86 \%$ & $\begin{array}{l}\text { Hellicopter Desease } \\
\text { (HD) }\end{array}$ & $100 \%$ \\
\hline 14 & $\begin{array}{l}\text { Dirty Cloaca area, } \\
\text { dehydration }\end{array}$ & $\begin{array}{l}\text { Infectious Bursal } \\
\text { Desease (IBD) }\end{array}$ & $\begin{array}{l}\text { Infectious Bursal } \\
\text { Desease (IBD) }\end{array}$ & $86 \%$ & $\begin{array}{l}\text { Infectious Bursal } \\
\text { Desease (IBD) }\end{array}$ & $100 \%$ \\
\hline 15 & $\begin{array}{l}\text { Dirty Cloaca area, no } \\
\text { appetite }\end{array}$ & $\begin{array}{l}\text { Infectious Bursal } \\
\text { Desease (IBD) }\end{array}$ & $\begin{array}{l}\text { Infectious Bursal } \\
\text { Desease (IBD) }\end{array}$ & $80 \%$ & $\begin{array}{c}\text { Infectious Bursal } \\
\text { Desease (IBD) }\end{array}$ & $100 \%$ \\
\hline
\end{tabular}




\begin{tabular}{|c|c|c|c|c|c|c|}
\hline 16 & $\begin{array}{l}\text { Swelling of the eye } \\
\text { next to, diarrhea, } \\
\text { inflammation under } \\
\text { the skin }\end{array}$ & Colibacillosis $(\mathrm{CO})$ & Colibacillosis (CO) & $91 \%$ & Colibacillosis (CO) & $100 \%$ \\
\hline 17 & $\begin{array}{l}\text { Diarrhea, } \\
\text { inflammation under } \\
\text { the skin }\end{array}$ & Colibacillosis $(\mathrm{CO})$ & Colibacillosis (CO) & $83 \%$ & Colibacillosis (CO) & $100 \%$ \\
\hline 18 & $\begin{array}{l}\text { Dull fur, green } \\
\text { diarrhea }\end{array}$ & Cholera $(\mathrm{K})$ & Cholera $(\mathrm{K})$ & $83 \%$ & Cholera (K) & $100 \%$ \\
\hline 19 & $\begin{array}{l}\text { Dull fur, diarrhea, } \\
\text { respiratorydisorders }\end{array}$ & Cholera $(\mathrm{K})$ & Chickenpox (CA) & $48 \%$ & Cholera $(\mathrm{K})$ & $50,4 \%$ \\
\hline 20 & $\begin{array}{l}\text { Sluggish, lazy move, } \\
\text { peck slimy feces }\end{array}$ & $\begin{array}{l}\text { Necrotic Enteritis } \\
\text { (NE) }\end{array}$ & $\begin{array}{l}\text { Necrotic Enteritis } \\
\text { (NE) }\end{array}$ & $79 \%$ & $\begin{array}{c}\text { Necrotic Enteritis } \\
\text { (NE) }\end{array}$ & $90 \%$ \\
\hline 21 & $\begin{array}{l}\text { Diarrhea, feces } \\
\text { sticking to the } \\
\text { cloaca, no appetite }\end{array}$ & $\begin{array}{l}\text { Necrotic Enteritis } \\
\text { (NE) }\end{array}$ & $\begin{array}{l}\text { Necrotic Enteritis } \\
\text { (NE) }\end{array}$ & $83 \%$ & $\begin{array}{l}\text { Necrotic Enteritis } \\
\text { (NE) }\end{array}$ & $100 \%$ \\
\hline 22 & $\begin{array}{l}\text { Dehydration, diluted } \\
\text { diarrhea rotten smell, } \\
\text { joints and soles of } \\
\text { the feet swollen }\end{array}$ & Salmonellosis (S) & Salmonellosis (S) & $94 \%$ & Salmonellosis (S) & $100 \%$ \\
\hline 23 & $\begin{array}{l}\text { Dilute diarrhea } \\
\text { smells rotten, curled, } \\
\text { not appetite }\end{array}$ & Salmonellosis (S) & Salmonellosis (S) & $90 \%$ & Salmonellosis (S) & $100 \%$ \\
\hline 24 & $\begin{array}{l}\text { Dilute diarrhea } \\
\text { smells rotten, } \\
\text { lethargic, curled } \\
\end{array}$ & Salmonellosis (S) & Salmonellosis (S) & $91 \%$ & Salmonellosis (S) & $100 \%$ \\
\hline 25 & $\begin{array}{l}\text { Diarrhea, lethargic, } \\
\text { lazy move, abnormal } \\
\text { fur growth }\end{array}$ & $\begin{array}{c}\text { Hellicopter } \\
\text { Desease (HD) }\end{array}$ & $\begin{array}{c}\text { Hellicopter } \\
\text { Desease (HD) }\end{array}$ & $90 \%$ & $\begin{array}{l}\text { Hellicopter Desease } \\
\text { (HD) }\end{array}$ & $100 \%$ \\
\hline 26 & $\begin{array}{l}\text { Decreased egg } \\
\text { production, head to } \\
\text { neck Tremor }\end{array}$ & $\begin{array}{c}\text { Avian } \\
\text { Encephalomytelitis } \\
\text { (AE) }\end{array}$ & $\begin{array}{c}\text { Avian } \\
\text { Encephalomytelitis } \\
\text { (AE) }\end{array}$ & $74 \%$ & $\begin{array}{c}\text { Avian } \\
\text { Encephalomytelitis } \\
\text { (AE) }\end{array}$ & $100 \%$ \\
\hline 27 & $\begin{array}{l}\text { Decreased egg } \\
\text { production, head } \\
\text { Tremor to } \\
\text { Leherparalysis, } \\
\text { decreased egg } \\
\text { production, Tremor } \\
\text { head to neck }\end{array}$ & $\begin{array}{c}\text { Avian } \\
\text { Encephalomytelitis } \\
\text { (AE) }\end{array}$ & $\begin{array}{c}\text { Avian } \\
\text { Encephalomytelitis } \\
\text { (AE) }\end{array}$ & $91 \%$ & $\begin{array}{c}\text { Avian } \\
\text { Encephalomytelitis } \\
\text { (AE) }\end{array}$ & $100 \%$ \\
\hline 28 & $\begin{array}{l}\text { Dehydration, no } \\
\text { appetite }\end{array}$ & Salmonellosis (S)) & $\begin{array}{l}\text { Infectious Bursal } \\
\text { Desease (IBD) }\end{array}$ & $40 \%$ & $\begin{array}{c}\text { Infectious Coryza } \\
\text { (SNOT). Infectious } \\
\text { Bursal Desease } \\
\text { (IBD), } \\
\text { Salmonellosis (S) }\end{array}$ & $60 \%$ \\
\hline 29 & Diarrhea, no appetite & $\begin{array}{l}\text { Necrotic Enteritis } \\
\text { (NE) }\end{array}$ & Colibacillus (CO) & $20 \%$ & $\begin{array}{c}\text { Infectious Coryza } \\
\text { (SNOT), Necrotic } \\
\text { Enteritis (NE) }\end{array}$ & $30 \%$ \\
\hline 30 & $\begin{array}{l}\text { Dehydration, fishy } \\
\text { eyes }\end{array}$ & $\begin{array}{c}\text { Infectious Coryza } \\
\text { (SNOT) }\end{array}$ & $\begin{array}{c}\text { Infectious Coryza } \\
\text { (SNOT) }\end{array}$ & $96 \%$ & $\begin{array}{c}\text { Infectious Coryza } \\
\text { (SNOT) }\end{array}$ & $100 \%$ \\
\hline 31 & $\begin{array}{l}\text { Dull feather, fishy } \\
\text { eyes }\end{array}$ & $\begin{array}{c}\text { Infectious Coryza } \\
(\text { SNOT })\end{array}$ & $\begin{array}{c}\text { Infectious Coryza } \\
\text { (SNOT) }\end{array}$ & $84 \%$ & $\begin{array}{c}\text { Infectious Coryza } \\
\text { (SNOT) }\end{array}$ & $100 \%$ \\
\hline 32 & $\begin{array}{l}\text { A gray-red bunker, } \\
\text { there is a Kerompeng }\end{array}$ & Chickenpox (CA) & Chickenpox (CA) & $100 \%$ & Chickenpox (CA) & $100 \%$ \\
\hline 33 & $\begin{array}{l}\text { A gray-red bunker, } \\
\text { there is a } \\
\text { Kerompeng, blackish } \\
\text { color }\end{array}$ & Chickenpox (CA) & Chickenpox (CA) & $97 \%$ & Chickenpox (CA) & $100 \%$ \\
\hline 34 & $\begin{array}{l}\text { Diarrhea, lethargic, } \\
\text { abnormal fur growth }\end{array}$ & $\begin{array}{c}\text { Hellicopter } \\
\text { Desease (HD) }\end{array}$ & $\begin{array}{c}\text { Hellicopter } \\
\text { Desease (HD) }\end{array}$ & $90 \%$ & $\begin{array}{l}\text { Hellicopter Desease } \\
\text { (HD) }\end{array}$ & $100 \%$ \\
\hline 35 & Dirty Cloaca area, & Infectious Bursal & Infectious Bursal & $83 \%$ & Infectious Bursal & $100 \%$ \\
\hline
\end{tabular}




\begin{tabular}{|c|c|c|c|c|c|c|}
\hline & peck the Cloaca area & Desease ( IBD) & Desease ( IBD) & & Desease ( IBD) & \\
\hline 36 & $\begin{array}{l}\text { There is mucous in } \\
\text { the mouth, sound } \\
\text { snoring }\end{array}$ & $\begin{array}{c}\text { Chronic } \\
\text { Respiratory } \\
\text { Disease (CRD) }\end{array}$ & $\begin{array}{c}\text { Chronic } \\
\text { Respiratory } \\
\text { Disease (CRD) }\end{array}$ & $100 \%$ & $\begin{array}{c}\text { Chronic Respiratory } \\
\text { Disease (CRD) }\end{array}$ & $100 \%$ \\
\hline 37 & $\begin{array}{l}\text { Diarrhea, } \\
\text { inflammation under } \\
\text { the skin }\end{array}$ & Colibacillosis (CO) & Colibacillosis (CO) & $80 \%$ & Colibacillosis (CO) & $100 \%$ \\
\hline 38 & $\begin{array}{l}\text { Green diarrhea, } \\
\text { increased respiratory } \\
\text { frequency }\end{array}$ & Cholera $(\mathrm{K})$ & Cholera a $(\mathrm{K})$ & $90 \%$ & Cholera $(\mathrm{K})$ & $100 \%$ \\
\hline 39 & $\begin{array}{l}\text { Dilute diarrhea } \\
\text { smells rotten, curled, } \\
\text { not appetite }\end{array}$ & Salmonellosis (S) & Salmonellosis (S) & $80 \%$ & Salmonellosis (S) & $100 \%$ \\
\hline 40 & $\begin{array}{l}\text { Swollen femur } \\
\text { joints, no appetite }\end{array}$ & Gout & Salmonellosis (S) & $64 \%$ & Gout & $90 \%$ \\
\hline
\end{tabular}

Expert system testing that has been built by incorporating symptoms of chicken disease. If there is a case that has more than one symptom it will use a combination calculation that will find the confidence level of both rules. If obtained the highest value of the combination then used to determine the diagnosis of disease in chickens.

Perform other tests by testing 40 cases, if the test results found on an expert system have the same value as an expert, it will be given a value of 1 . If the test result has a different value the meal will be given a value of 0 . If the belief value of the disease above $50 \%$ then the disease is the conclusion of the symptoms in the input. Comparative table of Expert results with the results of the expert system indicated by table 3 . After testing, a 40-case result was produced. From the test, the amount of accuracy is as follows:

$$
\begin{aligned}
\text { Akurasi }= & =\frac{38}{40} \times 100 \% \\
& =95 \%
\end{aligned}
$$

The result of the accuracy of the test conducted in 40 cases was $95 \%$.

\section{CONCLUSIONS}

From the research conducted and discussion of previous chapters, it can be concluded that : Dempster Shafer method is used successfully to determine uncertainty in taking conclusions on chicken disease, Expert system can help farmers to see diseases suffered by chickens due to the limitation of experts and Based on the tests conducted in 40 cases, obtained the percentage yield of $95 \%$.

\section{ACKNOWLEDGEMENTS}

The author thanked Allah SWT for his mercy, the author can complete this study well. The author also thanked the family, the father/Mother lecturer, Friends, and the parties who have given support for the success of this research. 


\section{REFERENCES}

[1] Badan Pusat Statistik, "Pengeluaran Untuk Konsumsi Penduduk Indonesia Per Provinsi”, 2018 [Online]. Available : http://www.bps.go.id/pengeluaran-untuk-konsumsipenduduk-indonesia-per-provinsi-maret-2018.html [Accessed: 20-Maret-2019]

[2] F.D. Retno et al, "Penyakit - Penyakit Penting Pada Ayam”. Bandung : Medion, 2015.

[3] Giarratano,.J., dan Riley, G., "Expert System : Principles and Programming “. USA : PWS Publishing Company, 2005.

[4] Rohajawati,S dan Supriadi,R., "Sistem Pakar Diagnosis Penyakit Unggas dengan Metode Certainty Factor", CommiT ( Communication and Information Technology, vol. 4, no. 1, pp.41-46, Mei. 2010.

[5] Darwan, "Sistem Pakar Sebagai Media Konsultasi Identifikasi Penyakit Flu Burung Pada Ayam dan Penanggulangganya", thesis, Jurusan Ilmu Komputer FMIPA UGM, 2007.

[6] Achmadi, S et al, "Expert System Design to Diagnos of Virus Infection Disease in Children with Certainty Factor Method", JSAE ( Journal of Science and Applied Engineering, vol.1, no.2, pp. 88-95, Oktober, 2018

[7] Setyohadi, DPS et al., "An Expert System for Diagnosis of Broiler Diseases using Certainty Factor", The 2nd International Joint Conference on Science and Technology (IJCST) . 2017.

[8] E. P. Gunawan dan R. Wardoyo, "An Expert System Using Certainty Factor for Determining Insomnia Acupoint" IJCCS (Indonesian J. Comput. Cybern. Syst., vol. 12, no. 2, pp. 119-128, July. 2018 [Online]. Available : https://jurnal.ugm.ac.id/ijccs/issue/view/3253 . [Accessed : 22-July-2020]

[9] Trismayanti, D.P., "Sistem Pakar Untuk Diagnosis Penyakit Pada Jamur Dengan Menggunakan Metode VCIRS dan Dempster Shafer”, thesis, Jurusan Ilmu Komputer FMIPA UGM, 2014.

[10] Efendi, Rusdi., "Sistem Pakar Mendiagnosisi Penyakit Endoparsitisme Gastrointestinal pada Hewan Ternak, Sapi dan Domba", thesis, Jurusan Ilmu Komputer FMIPA UGM, 2006.

[11] Tomatala, Michel., "Sistem Pakar Untuk Identifikasi dan Penanggulangan Masalah Budidaya Ikan Mas Menggunakan Metode Dempster Shafer”, thesis, Jurusan Ilmu Komputer FMIPA UGM, 2015.

[12] Aji, Luthfi., "Sistem Pakar Untuk Diagnosis Penyakit Mata Menggunakan Metode Dempster Shafer", thesis, Jurusan Ilmu Komputer FMIPA UGM, 2017.

[13] Kusumadewi, Sri, “Artificial Intelligence ( Teknik dan Aplikasi) “. Yogyakarta : Graha Ilmu, 2003. 
[14] Turban, E., "Decision Support and Expert Systems Management Support Systems". USA : Prentice-Hall, 1995. 